\title{
COVID-19 Lockdown and Eye Injury: A Case Series from Jordan
}

This article was published in the following Dove Press journal:

International Medical Case Reports Journal

\author{
Asem A Alqudah (D) \\ Rami A Al Dwairi' \\ Noor M Alqudah (D) \\ Sumayyah K Abumurad ${ }^{2}$ \\ 'Ophthalmology Service, Department of \\ Special Surgery, Faculty of Medicine, \\ Jordan University of Science and \\ Technology (JUST), Irbid, Jordan; \\ ${ }^{2}$ Department of Neurology, The \\ University of Chicago Medicine, Chicago, \\ IL, USA
}

\begin{abstract}
Novel coronavirus or COVID-19 is a viral illness that can cause severe respiratory symptoms. It spreads between people through direct, indirect (through contaminated objects or surfaces), or close contact with infected people via mouth and nose secretions. COVID-19 has caused a worldwide pandemic that necessitated many countries to perform a national lockdown. In Jordan, a complete lockdown was imposed by the government on March 17th, 2020 and continued for more than two months. The lockdown included every single sector in the country. Hospitals were only dealing with outpatient emergency cases, urgent referrals from primary or secondary health institutions and with inpatients whose medical conditions required keeping them admitted. Elective clinics and surgeries were canceled. At the King Abdullah University Hospital (KAUH), which is the only tertiary center in northern Jordan, we dealt with four cases of traumatic eye injury that resulted in a ruptured globe. The four cases were for eyes that had a history of penetrating keratoplasty (PK) and were visually compromised in the involved eye compared to the other eye. The percentage of open globe injuries to the total number of emergency cases presented during the lockdown was significantly higher than the percentage of open globe injuries to the total number of emergency cases presented during the corresponding period in the previous year ( $\mathrm{p}=0.0005$ ). We believe the lockdown inside homes has resulted in higher risk of trauma and rupture globe in this group of patients.
\end{abstract}

Keywords: COVID-19, lockdown, eye injury, PK

\section{Introduction}

Novel Coronavirus (COVID-19) is a new worldwide pandemic. The disease was first described in late December of 2019 as a viral pneumonia based on reports from the city of Wuhan, China. In the first two months of 2020, the disease spread around the world and more information became available about its nature. In February 2020, WHO announced that the disease would be named COVID-19. ${ }^{1}$ It was discovered that the virus belongs to the order Nidovirales, the family of Coronaviridae, and the genus Betacoronavirus. It is an enveloped virus containing a non-segmented positive-sense, and single-stranded ribonucleic acid (RNA). ${ }^{2}$

The virus results in mild (even no symptoms) to severe respiratory illness (Severe acute respiratory syndrome coronavirus 2 of the genus Betacoronavirus), it is transmitted chiefly by contact with infectious material (such as respiratory droplets) or with objects or surfaces contaminated by the causative virus. COVID19 is characterized especially by fever, cough, shortness of breath, and may progress to pneumonia and respiratory failure. ${ }^{3}$
Correspondence: Asem A Alqudah Ophthalmology Service, Department of Special Surgery, Faculty of Medicine, Jordan University of Science and Technology (JUST), P.O. Box 3030, Irbid 22110, Jordan

Tel +962795458496

Fax+962-27095010

Email asemq981@yahoo.com
International Medical Case Reports Journal 2020:13 493-50I 
Due to the fast transmissibility of the disease from the infected person to others, ${ }^{4}$ and the emergence of clusters and outbreaks between individuals, ${ }^{5}$ many governments around the world imposed lockdowns and/or social distancing in public areas. ${ }^{6}$ Jordan was not an exception; a strict lockdown was imposed by the Jordanian government on March 17th, and continued for more than two months. ${ }^{7}$ Although the government loosened the lockdown at different intervals to allow people to get their important needs, most sectors were completely closed. Hospitals were allowed only to deal with emergency cases and urgent referrals from other health-care centers.

Ophthalmology clinics were open only for emergency cases. In King Abdullah University Hospital (KAUH), patients were able to call the emergency service at the hospital and to be referred to the proper on-call physician for their concerns and questions. Patients with eye complaints were able to get in touch with the on-call ophthalmologists who used their judgment to determine the urgency of the problem and decided whether the patient needed to come to the ophthalmology emergency room (ER) or not. Since the ocular surface has been shown to be a possible route for COVID-19 transmission, ${ }^{8}$ ophthalmologists were instructed to follow clinical guidelines to face the pandemic and protect themselves and their patients from COVID-19 infection. These guidelines were based on recommendations from the American Academy of Ophthalmology (AAO), ${ }^{9}$ International Council of Ophthalmology (ICO), ${ }^{10}$ and on different published papers that discussed protocols and effective measures to prevent COVID-19 transmission. ${ }^{11-14}$ These recommendations included the use of protective goggles, face shields, slit lamp breath shields, disposable gloves, thorough hand washing with soap and water, and disinfection of examination rooms and slit lamps after each examination. In addition, general protective measures were strictly implemented inside the hospital such as the use of a face mask, social distancing, and body temperature measurement for every single patient.

The prolonged lockdown had an impact on peoples' social life and on their psychological health. ${ }^{15}$ People, including patients with compromised vision, had to stay inside their houses for longer periods of time. This could have negatively affected different aspects of their health and could have resulted in higher risk of trauma and injury.

In this case series, we describe four cases of ruptured globe that presented as emergency cases to the ophthalmology department at KAUH during the period of the two-month lockdown. All the involved eyes shared a history of previous penetrating keratoplasty (PK) and they were the worst seeing eyes in each patient. They also all shared the same form of rupture that involved large wound dehiscence and was associated with extrusion of the lens (whether crystalline or artificial) through the wound at the time of trauma. While literature shows that the majority of eye injuries occur at the workplace, followed by at home,${ }^{16-18}$ these four cases of open globe injuries all occurred at home.

King Abdullah University Hospital Institutional review board/ethics committee approval was required to publish the case details and obtained in accordance with the Health Insurance Portability and Accountability Act regulations. All patients, including the parents of the 8-year-old patient, provided written informed consent for publication of the case details and accompanying images.

\section{Case Report}

A 25-year-old Arabic Jordanian male patient presented to the ER of KAUH at around 9 pm during the second week of lockdown with a history of falling down in the house and suffered a direct hit to the right side of his face one hour prior to presentation. Immediately after impact he felt fluid coming from his right eye and lost vision in that eye. The patient's past ocular history is significant for having keratoconus in both eyes and history of hydrops in the right eye. PK was performed to the right eye seven months prior to presentation. His visual acuity (VA) at presentation was light perception (LP) in the right eye and 0.7 (1.4 Log MAR) in the left eye. Using the indirect pupillary reflex, right eye relative afferent pupillary defect (RAPD) was noticed. Examination of the right eye revealed complete dehiscence of the superior two-thirds of the donor tissues from the host with eversion of the donor tissue downward resulting in the endothelial part of the graft facing away from the globe. Figure 1 The patient was aphakic (was phakic prior to trauma) suggesting the lens was expelled from the eye through the wound or dropped into the vitreous body. Vitreous was also present in the anterior chamber. Four weeks prior to trauma, his visual acuity was 0.2 (0.70 Log MAR) in the right eye and 0.7 (1.4 Log MAR) in the left eye. The patient was admitted to the hospital and the involved eye was covered by a cartella eye-shield. Six hours after presentation, the patient was sent to the operating room (OR). Primary repair under general anesthesia and sterile conditions using 9 stitches of 10/0 nylon sutures with anterior vitrectomy was done. 


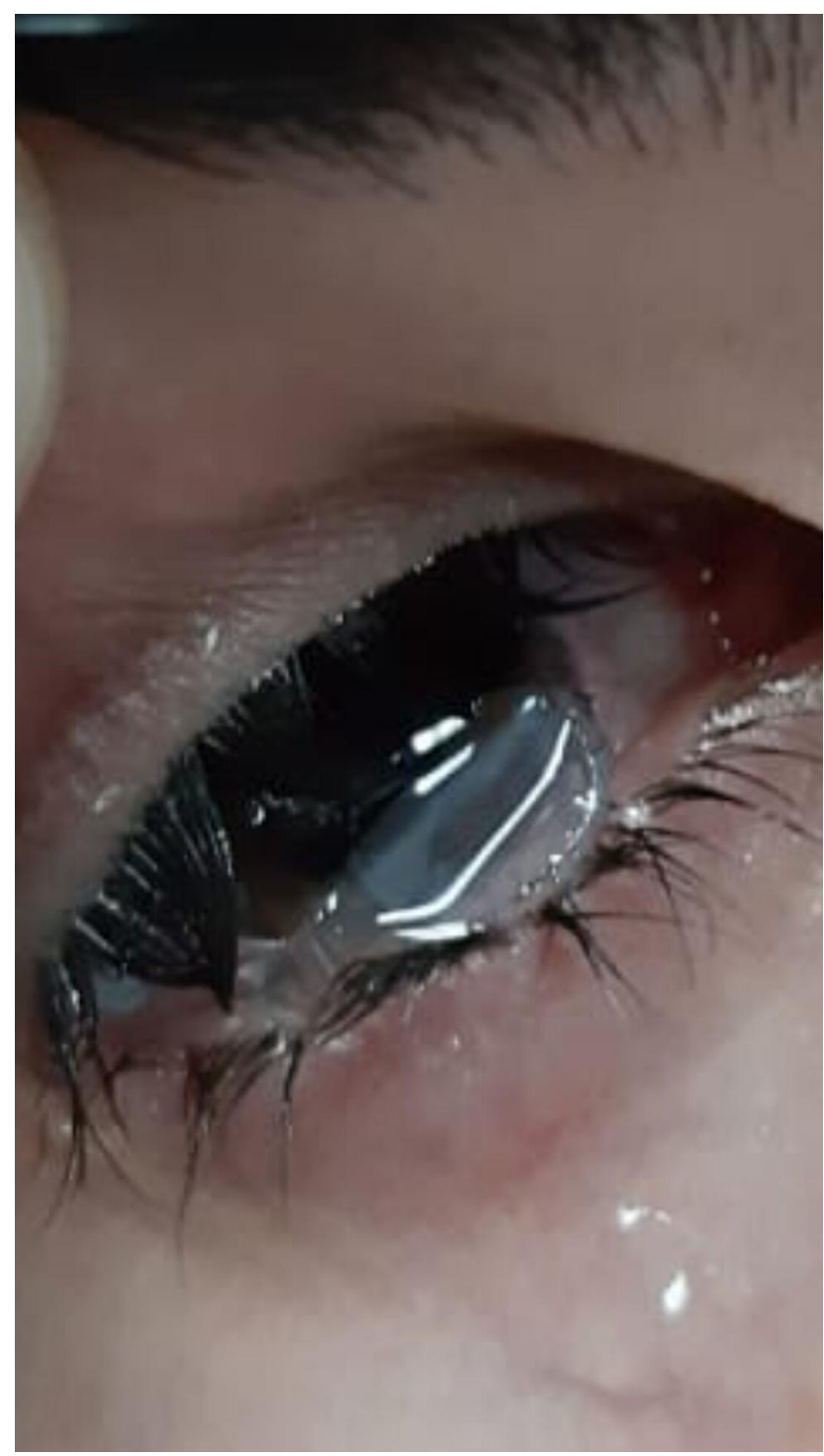

Figure I Picture of the eye at presentation in the first case showing dehiscence of the superior two thirds of the donor tissue from the host with eversion of the donor tissue downward resulting in the endothelial part of the graft facing away from the globe.

The wound was tested and found watertight and $0.1 \mathrm{cc}$ of Vigamox $0.5 \%$ (Alcon, Geneva, Switzerland) was injected in the anterior chamber (AC) at the end of the surgery. At day one postoperative, a B-scan ultrasonography (Sonomed AB5500+ E-Z Scan, NY, USA) was performed. The B-scan revealed no lens in the vitreous body and a complete retinal detachment $(\mathrm{RD})$ with vitreous hemorrhage $(\mathrm{VH})$. The patient was referred to a vitreoretinal surgeon. Figure 2 Steroid (Pred Forte 1\%, Allergan, Dublin, Ireland) and antibiotic (Vigamox $0.5 \%$, Alcon, Geneva, Switzerland) eye drops were given four times/ day in the first postoperative day. The antibiotic eye drops were stopped two weeks postoperative and the

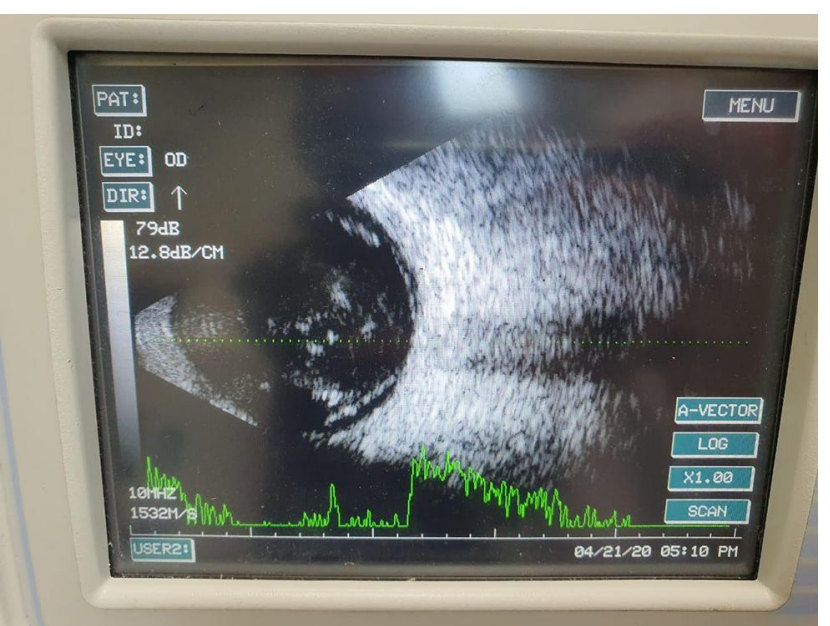

Figure 2 B-scan ultrasonography of the eye for the first case one day postoperatively showing vitreous hemorrhage and complete retinal detachment.

steroid eye drops were tapered over a month to twice daily. The cornea was edematous intraoperatively and continued to be edematous on further follow-up examinations suggesting secondary graft failure. The plan was to do pars plana vitrectomy (PPV) with RD repair, secondary iris fixation intraocular lens (IOL) and PK using temporary keratoprosthesis intraoperatively. The patient was notified of the uncertainty of the surgical outcome because of the comorbidities from retina damage due to the trauma.

In the third week of lockdown, a 48-year-old Arabic Jordanian female patient presented to the ER of KAUH at $3 \mathrm{pm}$ after reportedly walking into a wall and suffered a direct hit to the left side of her face. Immediately after impact, she felt pain, loss of vision, and softening of the left eye. The trauma was half an hour prior to presentation. The past ocular history was significant for keratoconus in both eyes, for which PK was performed to the left eye 12 years ago. The patient also developed steroid-induced glaucoma with subtotal optic disc cupping in the left eye. Her last eye exam six weeks prior to the lockdown showed a VA of 0.3 (0.5 Log MAR) in the right eye and counting fingers $(\mathrm{CF})$ at $1 \mathrm{~m}$ in the left eye. Her intraocular pressure was controlled in the left eye on three agents of antiglaucoma eye drops. Upon examination in the ER, VA was 0.3 ( $0.5 \log$ MAR) in the right eye and hand motion (HM) in the left eye. Left eye RAPD was seen and a complete dehiscence of the inferior half of the donorhost junction. The eye was also absent of a crystalline lens and vitreous was incarcerated in the wound. The patient was admitted to the hospital and the left eye was covered with a cartella eye-shield. Three hours after 
presentation, the patient was transferred to the OR and primary wound repair using 8 stitches of 10/0 nylon sutures with anterior vitrectomy was done under GA and sterile conditions. The wound was tested and found watertight and 0.1 cc of Vigamox $0.5 \%$ (Alcon, Geneva, Switzerland) was injected in the $\mathrm{AC}$ at the end of the surgery. In the first postoperative day, the B-scan ultrasonography (Sonomed AB5500+ E-Z Scan, NY, USA) was performed and revealed no RD. There was also no evidence of a crystalline lens in the posterior segment of the eye indicating the lens was expelled from the wound at the time of trauma. The patient was given a steroid (Pred Forte 1\%, Allergan, Dublin, Ireland) and antibiotic (Vigamox $0.5 \%$, Alcon, Geneva, Switzerland) eye drops, each four times/day. The antibiotic eye drops were stopped after two weeks and the steroid eye drops were tapered over a month to once/day. On subsequent postoperative follow up examinations, the VA in the left eye was CF and the patient progressively developed graft edema mandating a second PK with secondary iris fixation IOL. The patient was counselled regarding the risks vs benefits of a second PK with IOL and she chose not to go for surgery for the time being.

In the fourth week of lockdown, an eight-year-old Arabic Jordanian female patient presented to the ER with left eye trauma from falling down off her bed. Her past ocular history is significant for a ruptured globe two years ago (February of 2018) which resulted in subsequent cataract development and central corneal scarring. Phacoemulsification and IOL implantation in the bag was done three months later (May of 2018), and PK was done four months prior to the current presentation (December of 2019). Her last eye exam before the lockdown revealed a VA of 1.0 (0 Log MAR) in the right eye and 0.1 (1.0 Log MAR) in the left eye. The corneal graft in the left eye was clear and the eye was pseudophakic. Upon examination in the ER, VA was 1.0 (0 Log MAR) in the right eye and HM in the left eye. There was no RAPD. Wound dehiscence temporally from 11 to 4 o'clock was seen, the IOL was expelled outside the wound, the posterior capsule was disrupted, and vitreous was seen to be incarcerated in the wound. The patient was admitted to the hospital, a cartella eye-shield was applied to the involved eye and the patient was transferred to the OR after one hour of presentation. Under GA and sterile conditions, primary wound repair using 6 stitches of 10/0 nylon sutures with anterior vitrectomy was performed. The wound was tested and found watertight and $0.1 \mathrm{cc}$ of Vigamox $0.5 \%$ (Alcon, Geneva,
Switzerland) was injected in the anterior chamber (AC) at the end of the surgery. B-scan ultrasonography (Sonomed AB5500+ E-Z Scan, NY, USA) in the first postoperative day showed a flat retina and clear vitreous. Steroid (Pred Forte 1\%, Allergan, Dublin, Ireland) and antibiotic (Vigamox 0.5\%, Alcon, Geneva, Switzerland) eye drops were instructed to be used four times/day. The antibiotic eye drops were stopped after two weeks and the steroid eye drops were tapered over a month to two times/day. Subsequent eye exams for the involved eye showed a VA of CF at 3 meters, a clear graft, and aphakia. The plan in the last visit was to do secondary iris fixation artisan IOL.

In the sixth week of lockdown, a 42-year-old Arabic Jordanian female patient presented to the ER with right eye trauma two hours prior to presentation. The injury was caused by a direct hit from a closet door when the patient opened it. Eye exam at the ER showed a VA of HM in the right eye and 0.7 (1.4 Log MAR) in the left eye. There was no RAPD and a slit lamp exam showed a donor-host wound dehiscence of about six clock hours involving the superior half of a previously implanted corneal graft (PK), iris prolapse from the wound, and total hyphema. Lens and retina status could not be assessed. Past ocular history was significant for keratoconus in both eyes and PK in her right eye was done fifteen years ago. The patient stated the PK was the only ocular procedure she received in her life. The patient was not a regular patient in our department and no previous records could be obtained. However, the patient stated her vision was better in the left eye than in the right eye prior to trauma. She was admitted to the hospital, a cartella eye-shield was applied to the right eye and the patient was transferred to the OR after five hours from presentation. Primary wound repair under GA and sterile conditions using 7 stitches of 10/0 nylon sutures with anterior vitrectomy and anterior chamber washout was performed. Also, part of the incarcerated iris was cut and removed. The wound was tested and found watertight and 0.1 cc of Vigamox $0.5 \%$ (Alcon, Geneva, Switzerland) was injected in the anterior chamber (AC) at the end of the surgery. Patient was found intraoperatively to be aphakic with large iridodyalsis. Steroid (Pred Forte 1\%, Allergan, Dublin, Ireland) and antibiotic (Vigamox 0.5\%, Alcon, Geneva, Switzerland) eye drops were given to be used four times/day. The antibiotic eye drops were stopped after two weeks and the steroid eye drops were tapered over a month period to two times/day. One week postoperatively, the best corrected VA was 0.1 (1.0 Log MAR) in the right eye and 0.7 (1.4 Log MAR) in the left eye. The 


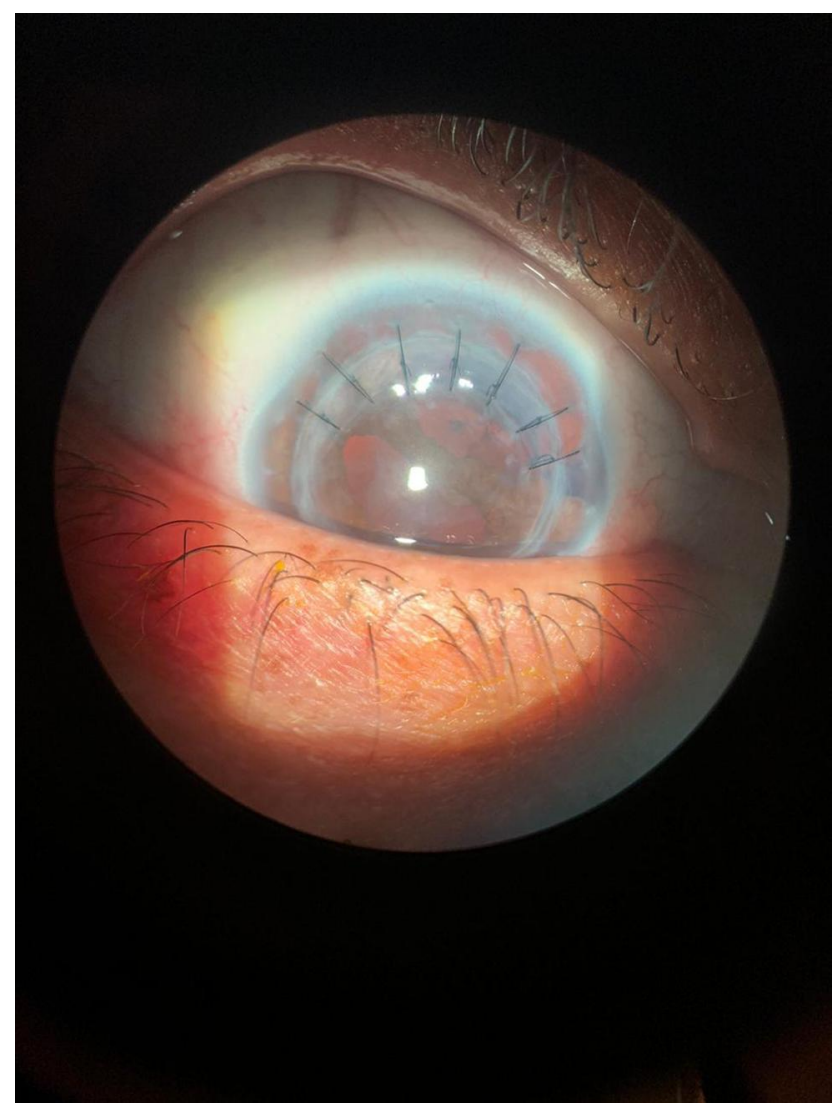

Figure 3 Slit lamp picture of the eye for the fourth case one week post-operatively showing seven 10/0 nylon stitches securing the area of donor-host junction dehiscence superiorly and a large iridodialysis superiorly and superionasally.

patient was aphakic with large iridodialysis. Figure 3 Fundus exam showed minimal $\mathrm{VH}$ but otherwise normal looking fundus. There was no evidence of any lenticular matter in the posterior segment, indicating the lens was expelled from the wound at the time of trauma. The plan in the last visit was to do iridodialysis repair and secondary scleral fixation IOL at a later occasion.

All patients were seen and followed up in the emergency ophthalmology clinic at KAUH. Table 1 summarizes the clinical scenarios of the four cases.

The number of ruptured globe cases that presented to the ER at KAUH during the period of strict lockdown and the number of ruptured globe cases that presented to the same ER in the year preceding the lockdown were recorded. The difference in the rate (number of cases/ time frame) between the two time periods were compared. $\mathrm{P}$ value was computed from a $2 \times 2$ contingency table using Fisher's exact test. The same method was used to compare the difference between the rate of inside-home trauma resulting in ruptured globe and the number of PKs presenting with ruptured globe due to trauma during the period of strict lockdown and the year preceding it. In addition, the percentage of open globe injuries out of the total number of ophthalmology emergency cases presented to the ER during the lockdown was compared to the percentage of open globe injuries out of the total number of ophthalmology emergency cases presented to the same ER during the year previous to the lockdown. The same statistical method was used to compute the $\mathrm{p}$ value and determine the clinical significance.

\section{Discussion}

In this small case series, we have noticed a possible correlation between COVID-19 lockdown and a high rate of eye trauma in patients who are visually compromised. We have also noticed that trauma has resulted in severe eye injury (rupture) and high rate of complications in eyes with PK.

Previous studies have shown different factors that increase the risk of eye trauma, which include male gender, cigarette smoking, younger age, and alcohol consumption. $^{16,19}$ It was also shown that the majority of the eye injuries occurred at the workplace, followed by at home. $^{16-18}$

Other studies have also shown the impact of visual disability on the quality of life. ${ }^{20}$ It has been shown that patients with vision disability are at higher risk to have trauma, falls, and injuries, including eye injuries. ${ }^{21,22}$

Patients with PK are at a higher risk of wound dehiscence after trauma. ${ }^{23-29}$ This is attributed to the fact that the donor-host junction never heals to gain the tensile strength of normal cornea. Another possibility is that chronic treatment of topical corticosteroid may delay healing and contribute more to the wound weakness. ${ }^{23-29}$ It has also been shown that poor visual outcomes in such injuries are common and may result in secondary graft failure, secondary glaucoma, and involvement of the posterior segment. $^{24-27}$

COVID-19 is a new pandemic that swept over the world in 2020, for which most countries imposed strict lockdowns. These lockdowns forced people to stay weeks and even months inside their houses. This has resulted in many social, ${ }^{30}$ psychological, $^{31}$ and even physical $^{32}$ effects on people, especially those with chronic illnesses. ${ }^{33}$

Patients with chronic eye disease have been negatively affected by the lockdowns. This was primarily caused by the cancellation of elective eye clinics, elective surgeries, the inability of the patients to do their regular follow up visits, and/or to get their medication prescriptions which resulted in 
Table I Summary of Clinical Scenarios for Patients Who Presented with Eye Injury Resulting in Ruptured Globe at KAUH During COVID-19 Lockdown in Jordan

\begin{tabular}{|c|c|c|c|c|}
\hline & Patient I & Patient 2 & Patient 3 & Patient 4 \\
\hline $\begin{array}{l}\text { Patient's } \\
\text { Profile }\end{array}$ & 25 Years, Male & 48 Years, Female & 8 Years, Female & 42 Years, Female \\
\hline PMH & Free & Essential HT & Free & Free \\
\hline $\mathrm{POH}$ & $\begin{array}{l}\text { I. KC OU. } \\
\text { 2. Corneal hydrops OD. } \\
\text { 3. PK OD } 7 \text { months prior to } \\
\text { presentation. }\end{array}$ & $\begin{array}{l}\text { I. KC OU } \\
\text { 2. PK OS } 12 \text { years ago } \\
\text { 3. Advanced steroid- } \\
\text { response glaucoma OS }\end{array}$ & $\begin{array}{l}\text { I. Ruptured globe } \\
\text { OS with primary } \\
\text { repair } 2 \text { years ago. } \\
\text { 2. Traumatic } \\
\text { cataract OS with } \\
\text { Phaco+PCIOL } 2 \\
\text { years ago. } \\
\text { 3. PK OS } 4 \text { months } \\
\text { ago }\end{array}$ & $\begin{array}{l}\text { I. KC OU } \\
\text { 2. PK OD I5 years ago. } \\
\text { 3. Patient stated VA was always } \\
\text { better in the left eye than in the } \\
\text { right one. }\end{array}$ \\
\hline $\begin{array}{l}\text { Last eye exam } \\
\text { prior to } \\
\text { presentation }\end{array}$ & $\begin{array}{l}\text { I. VA: } 0.2 \text { OD, } 0.7 \text { OS. } \\
\text { 2. Clear graft OD } \\
\text { 3. Phakic OU }\end{array}$ & $\begin{array}{l}\text { I. VA: } 0.3 \text { OD, CF Im } \\
\text { OS. } \\
\text { 2. RAPD OS. } \\
\text { 3. Clear graft OS. } \\
\text { 3. Phakic OU } \\
\text { 4. Cupped disc OS. }\end{array}$ & $\begin{array}{l}\text { I. VA: I.0 OD, } 0.1 \\
\text { OS. } \\
\text { 2. Clear graft OS } \\
\text { 3. Pseudophakia OS }\end{array}$ & $\begin{array}{l}\text { Not Available, the patient was not a } \\
\text { regular patient in our department. }\end{array}$ \\
\hline $\begin{array}{l}\text { Involved eye in } \\
\text { the trauma }\end{array}$ & OD & OS & OS & OD \\
\hline $\begin{array}{l}\text { Mechanism of } \\
\text { trauma }\end{array}$ & $\begin{array}{l}\text { Tripped and fell down in the house on } \\
\text { the right side of the body with a direct } \\
\text { hit to the right side of the face. }\end{array}$ & $\begin{array}{l}\text { Direct hit to the left } \\
\text { side of her face from a } \\
\text { wall while walking in } \\
\text { the house. }\end{array}$ & $\begin{array}{l}\text { Falling from bed } \\
\text { while sleeping }\end{array}$ & $\begin{array}{l}\text { Direct hit from a closet door when } \\
\text { the patient opened it. }\end{array}$ \\
\hline $\begin{array}{l}\text { Clinical exam } \\
\text { at presentation } \\
\text { and injury } \\
\text { description }\end{array}$ & $\begin{array}{l}\text { I. VA: LP OD, } 0.7 \text { OS. } \\
\text { 2. RAPD OD } \\
\text { 3. Dehiscence of the superior two } \\
\text { thirds of the donor tissues from the } \\
\text { host with eversion of the donor tissue } \\
\text { downward. } \\
\text { 4. Lens extrusion/Aphakia } \\
\text { 5. Vitreous prolapse } \\
\text { 6. Total RD } \\
\text { 7. VH }\end{array}$ & $\begin{array}{l}\text { I. VA: } 0.3 \text { OD, HM OS } \\
\text { 2. RAPD OS } \\
\text { 3. Dehiscence of the } \\
\text { inferior half of the } \\
\text { donor-host junction. } \\
\text { 4. Lens extrusion/ } \\
\text { Aphakia. } \\
\text { 5. Vitreous prolapse } \\
\text { and incarceration in } \\
\text { the wound. }\end{array}$ & $\begin{array}{l}\text { I. VA: I.0 OD, HM } \\
\text { OS } \\
\text { 2. No RAPD } \\
\text { 3. Donor-host } \\
\text { wound dehiscence } \\
\text { temporally from II } \\
\text { to } 4 \text { o'clock. } \\
\text { 4. IOL was expelled } \\
\text { outside the wound, } \\
\text { and the PC was } \\
\text { disrupted. } \\
\text { 5. Vitreous } \\
\text { prolapse and } \\
\text { incarceration in the } \\
\text { wound }\end{array}$ & $\begin{array}{l}\text { I. VA: HM OD, } 0.7 \text { OS. } \\
\text { 2. No RAPD } \\
\text { 3. Donor-host wound dehiscence } \\
\text { of about six clock hours superiorly. } \\
\text { 4. Iris prolapse } \\
\text { 5. Vitreous prolapse } \\
\text { 6. Total Hyphema } \\
\text { 7. Lens extrusion/Aphakia } \\
\text { 8. Iridodialysis }\end{array}$ \\
\hline $\begin{array}{l}\text { Surgery } \\
\text { performed }\end{array}$ & $\begin{array}{l}\text { Primary wound repair with anterior } \\
\text { vitrectomy }\end{array}$ & $\begin{array}{l}\text { Primary wound repair } \\
\text { with anterior } \\
\text { vitrectomy }\end{array}$ & $\begin{array}{l}\text { Primary wound } \\
\text { repair with anterior } \\
\text { vitrectomy }\end{array}$ & $\begin{array}{l}\text { Primary wound repair with anterior } \\
\text { vitrectomy and } A C \text { washout, some } \\
\text { prolapsing iris tissue was cut and } \\
\text { removed. }\end{array}$ \\
\hline
\end{tabular}

(Continued) 
Table I (Continued).

\begin{tabular}{|c|c|c|c|c|}
\hline & Patient I & Patient 2 & Patient 3 & Patient 4 \\
\hline $\begin{array}{l}\text { Patient's } \\
\text { Profile }\end{array}$ & 25 Years, Male & 48 Years, Female & 8 Years, Female & 42 Years, Female \\
\hline $\begin{array}{l}\text { Postoperative } \\
\text { last exam of } \\
\text { the involved } \\
\text { eye }\end{array}$ & $\begin{array}{l}\text { I. VA: LP } \\
\text { 2. RAPD } \\
\text { 3. Corneal edema/secondary graft } \\
\text { failure. } \\
\text { 4. Aphakia } \\
\text { 5. Total RD }\end{array}$ & $\begin{array}{l}\text { I. VA: CF. } \\
\text { 2. RAPD } \\
\text { 3. Corneal edema/ } \\
\text { secondary graft failure. } \\
\text { 4. Aphakia } \\
\text { 5. Subtotal disc } \\
\text { cupping }\end{array}$ & $\begin{array}{l}\text { I. VA: CF } 3 \text { meters } \\
\text { 2. Clear graft } \\
\text { 3. Aphakia }\end{array}$ & $\begin{array}{l}\text { I. VA: } 0.1 \\
\text { 2. Clear graft } \\
\text { 3. Iridodialyis superiorly and } \\
\text { superionasally. } \\
\text { 4. Aphakia } \\
\text { 5. Minimal VH }\end{array}$ \\
\hline Future plan & $\begin{array}{l}\text { I. PPV with RD repair. } \\
\text { 2. Iris fixation IOL implantation } \\
\text { 3. PK } \\
\text { 4. Temporary keratoprosthesis to be } \\
\text { used intraoperatively. } \\
\text { 5. Patient was notified the uncertainty } \\
\text { of the surgical outcome. }\end{array}$ & $\begin{array}{l}\text { I. PK } \\
\text { 2. Iris fixation IOL } \\
\text { implantation } \\
\text { 3. Patient chose to } \\
\text { wait for the time being }\end{array}$ & $\begin{array}{l}\text { Iris fixation IOL } \\
\text { implantation }\end{array}$ & $\begin{array}{l}\text { I. Iridodialysis repair } \\
\text { 2. Secondary scleral fixation IOL } \\
\text { implantation. }\end{array}$ \\
\hline
\end{tabular}

Abbreviations: KC, keratoconus. OU, both eyes. OD, right eye; OS, left eye; PK, penetrating keratoplasty; VA, visual acuity; LP, light perception; RAPD, relative afferent pupillary defect; RD, retinal detachment; PPV, pars plana vitrectomy; IOL, intra-ocular lens; HT, hypertension; CF, counting fingers; HM, hand motion; Phaco, phacoemulsification; $\mathrm{PCIOL}$, posterior chamber intra-ocular lens; $\mathrm{VH}$, vitreous hemorrhage.

Table 2 Number of Total Ocular Emergencies and Open Globe Injuries Presented to the ER at KAUH During the Lockdown

\begin{tabular}{|l|l|l|l|l|}
\hline $\begin{array}{l}\text { Total Cases of } \\
\text { Open Globe } \\
\text { Injuries }\end{array}$ & $\begin{array}{l}\text { Open Globe Injuries in } \\
\text { Eyes with History of PK }\end{array}$ & $\begin{array}{l}\text { Inside-Home } \\
\text { Open Globe } \\
\text { Injuries }\end{array}$ & $\begin{array}{l}\text { Total Number of } \\
\text { Ocular } \\
\text { Emergencies }\end{array}$ & $\begin{array}{l}\text { Percentage of Open Globe Injuries } \\
\text { to the Total Ocular Emergencies }\end{array}$ \\
\hline 4 & 4 & 4 & 34 & $12 \%$ \\
\hline
\end{tabular}

Abbreviations: ER, emergency room. PK, penetrating keratoplasty. KAUH, King Abdullah University Hospital.

Table 3 Number of Open Globe Injuries Presented to the ER at KAUH in the Year Preceding the Lockdown and p values when Compared to the Period of Lockdown

\begin{tabular}{|l|l|l|l|l|l|}
\hline $\begin{array}{l}\text { Total } \\
\text { Number } \\
\text { of Open } \\
\text { Globe } \\
\text { Injuries }\end{array}$ & $\begin{array}{l}\text { Open Globe } \\
\text { Injuries in } \\
\text { Eyes } \\
\text { with History } \\
\text { of PK }\end{array}$ & $\begin{array}{l}\text { Inside- } \\
\text { Home } \\
\text { Open } \\
\text { Globe } \\
\text { Injuries }\end{array}$ & $\begin{array}{l}\text { P value for Difference } \\
\text { Between the Rate of Open } \\
\text { Globe Injuries During the } \\
\text { Strict Lockdown Period and } \\
\text { the Year Preceding it }\end{array}$ & $\begin{array}{l}\text { P value for the Difference } \\
\text { Between the Rate of Open } \\
\text { Globe Injuries in Eyes with } \\
\text { Previous PKs During the } \\
\text { Strict Lockdown Period and } \\
\text { the Year Preceding it }\end{array}$ & $\begin{array}{l}\text { P value for the Difference } \\
\text { Between the Rate of Inside- } \\
\text { Homen Opobe Injuries } \\
\text { During the Strict Lockdown } \\
\text { Period and the Year } \\
\text { Preceding it }\end{array}$ \\
\hline II & $\mathrm{I}$ & 3 & 0.3 & 0.007 & 0.03 \\
\hline
\end{tabular}

Abbreviations: ER, emergency room. PK, penetrating keratoplasty. KAUH, King Abdullah University Hospital.

Table 4 Number of Total Ocular Emergencies and Open Globe Injuries Presented to the ER at KAUH During the Corresponding Period of the Previous Year and $p$ value When Compared to the Period of Lockdown

\begin{tabular}{|l|l|l|l|}
\hline $\begin{array}{l}\text { Total Cases of } \\
\text { Open Globe } \\
\text { Injuries }\end{array}$ & $\begin{array}{l}\text { Total Number } \\
\text { of Ocular } \\
\text { Emergencies }\end{array}$ & $\begin{array}{l}\text { Percentage of Open Globe } \\
\text { Injuries to the Total Ocular } \\
\text { Emergencies }\end{array}$ & $\begin{array}{l}\text { P value for the Difference Between the Rate of Open } \\
\text { Globe Injuries to the Total Ophthalmology Emergency } \\
\text { Cases During the Lockdown Compared to the } \\
\text { Corresponding Period of the Last Year. }\end{array}$ \\
\hline $\mathrm{I}$ & 288 & $0.3 \%$ & 0.0005 \\
\hline
\end{tabular}

Abbreviations: ER, emergency room. PK, penetrating keratoplasty. KAUH, King Abdullah University Hospital. 
a delay in receiving proper management. For example, the duration of lockdown was found to be directly proportional to the worsening of diabetic retinopathy. ${ }^{34}$ In order to decrease the negative health effect of the lockdown on patients with eye diseases, different ophthalmology societies and scholars all around the world prepared for resumption of eye care and published documents detailing how to reopen more normal practices in the COVID-19 era. The reopening was based on the disease epidemiological situation in each local area and on implementing guidelines and strict protective measures to protect patients and health-care workers during the pandemic. ${ }^{14}$

In the year preceding the COVID-19 lockdown, the ophthalmology department at KAUH dealt with 11 cases of ruptured globe, three of which resulted from trauma inside houses, and only one of which was in a form of wound dehiscence of a PK. Although the difference between the rate of ruptured globe cases during the strict lockdown period and the year preceding it was not clinically significant $(p=0.3)$, we believe this could have resulted from the small number of cases overall. Nevertheless, the difference in the rate of inside-home trauma resulting in ruptured globe and the number of PKs presenting with ruptured globe due to trauma were significantly higher during the lockdown $(p=0.03$ and $p=0.007$, respectively).

The four cases described in the manuscript represent all cases of open globe injuries presented during the strict period of lockdown. Only one case of open globe injury presented to the ER department of the same hospital during the corresponding period last year.

There was a total of 34 cases that presented to the ophthalmology service ER at KAUH during strict lockdown. These represented different cases of ophthalmic emergencies including trauma (10 cases including the four open globe injuries described in this report), loss of vision ( 5 cases), eye pain ( 7 cases) and redness (12 cases). The total number of cases presented to the ophthalmology service ER during the corresponding period last year was 288. The much lower total number of emergency cases presented during the lockdown compared to the corresponding period of the previous year is attributed to the fact that a strict curfew was imposed by the government, and only patients with highly emergent cases were allowed to call the civil defense department and get transferred to hospitals. This has resulted in a very high threshold for patients to present to emergency departments in hospitals.

The percentage of open globe injuries out of the total number of ophthalmic emergency cases was $4 / 34(12 \%)$ during the lockdown compared to $1 / 288(0.3 \%)$ during the corresponding period of the last year. This difference is clinically significant $(\mathrm{p}=0.0005)$.

All data and results presented in this manuscript are summarized in Tables 2 to 4 .

We believe that the duration of lockdown could have resulted in higher risk of eye trauma in visually compromised patients. This may be due to the psychological impact of the lockdown, and/or as a direct effect of staying within a limited space inside the house for a long period of time. As a consequence of the structural weakness of eyes with previous PKs, these eyes were more likely to present with wound dehiscence and more severe damage that required urgent surgical interventions. Four cases of ruptured globe, all of which were in a form of large wound dehiscence and lens extrusion in eyes with previous PKs, and all presenting in one center within five weeks during the period of lockdown, represent an extremely unusual scenario that deserves reporting.

\section{Disclosure}

The authors report no conflicts of interest for this work.

\section{References}

1. Available from: https://www.who.int/news-room/detail/29-06-2020covidtimeline. Accessed September 22, 2020.

2. Pal M, Berhanu G, Desalegn C, Kandi V. Severe Acute Respiratory Syndrome Coronavirus-2 (SARS-CoV-2): an update. Cureus. 2020;12(3):e7423. doi:10.7759/cureus.7423

3. Ludwig S, Zarbock A. Coronaviruses and SARS-CoV-2: a brief overview. Anesth Analg. 2020;131(1):93-96. doi:10.1213/ANE.00 00000000004845

4. Available from: https://www.ecdc.europa.eu/en/covid-19/latest-evi dence/transmission. Accessed September 22, 2020.

5. Desjardins MR, Hohl A, Delmelle EM. Rapid surveillance of COVID-19 in the United States using a prospective space-time scan statistic: detecting and evaluating emerging clusters. Appl Geogr. 2020;118:102202. doi:10.1016/j.apgeog.2020.102202

6. Wilder-Smith A, Bar-Yam Y, Fisher D. Lockdown to contain COVID-19 is a window of opportunity to prevent the second wave. J Travel Med. 2020;27(5):taaa091. doi:10.1093/jtm/taaa091

7. Alqutob R, Al Nsour M, Tarawneh MR, et al. COVID-19 Crisis in Jordan: response, scenarios, strategies, and recommendations. JMIR Public Health Surveill. 2020;6(3):e19332. doi:10.2196/19332

8. Napoli PE, Nioi M, d'Aloja E, Fossarello M. The ocular surface and the Coronavirus disease 2019: does a dual 'Ocular route' exist? $J$ Clin Med. 2020;9(5):1269. doi:10.3390/jcm9051269

9. American Academy of Ophthalmology. Important coronavirus updates for ophthalmologists. Available from: https://www.aao.org/headline/ alert-important-coronavirus-context.37. Accessed September 22, 2020.

10. International Council of Ophthalmology. ICO Global COVID-19 Resource Center. Available from: http://www.icoph.org/news/news detail/602/ICO-Global-COVID-19-Resource-Center.html. Accessed September 22, 2020.

11. Gharebaghi R, Desuatels J, Moshirfar M, Parvizi M, Daryabari SH, Heidary F. COVID-19: preliminary clinical guidelines for ophthalmology practices. Med Hypothesis Discov Innov Ophthalmol. 2020;9 (2):149-158. 
12. Pei X, Jiao X, Lu D, Qi D, Huang S, Li Z. How to face COVID-19 in ophthalmology practice. Med Hypothesis Discov Innov Ophthalmol. 2020;9(3):164-171.

13. $\mathrm{Hu} \mathrm{VH,} \mathrm{Watts} \mathrm{E,} \mathrm{Burton} \mathrm{M,} \mathrm{et} \mathrm{al.} \mathrm{Protecting} \mathrm{yourself} \mathrm{and} \mathrm{your}$ patients from COVID-19 in eye care. Community Eye Health. 2020;33(108):S1-S6.

14. Napoli PE, Nioi M, d'Aloja E, Fossarello M. Safety recommendations and medical liability in ocular surgery during the COVID-19 pandemic: an unsolved dilemma. J Clin Med. 2020;9(5):1403. doi:10.3390/jcm9051403

15. Hiremath P, Suhas Kowshik CS, Manjunath M, Shettar M. COVID 19: impact of lock-down on mental health and tips to overcome. Asian J Psychiatr. 2020;51:102088. doi:10.1016/j.ajp.2020.102088

16. Loon SC, Tay WT, Saw SM, Wang JJ, Wong TY. Prevalence and risk factors of ocular trauma in an urban south-east Asian population: the Singapore Malay Eye Study. Clin Exp Ophthalmol. 2009;37(4):362367. doi:10.1111/j.1442-9071.2009.02035.x

17. Nirmalan PK, Katz J, Tielsch JM, et al. Ocular trauma in a rural south Indian population: the Aravind Comprehensive Eye Survey. Ophthalmology. 2004;111(9):1778-1781. doi:10.1016/j.ophtha.2004. 02.012

18. Voon LW, See J, Wong TY. The epidemiology of ocular trauma in Singapore: perspective from the emergency service of a large tertiary hospital. Eye (Lond). 2001;15(Pt 1):75-81. doi:10.1038/eye.2001.18

19. Chua D, Wong W, Lamoureux EL, Aung T, Saw SM, Wong TY. The prevalence and risk factors of ocular trauma: the Singapore Indian eye study. Ophthalmic Epidemiol. 2011;18(6):281-287. doi:10.3109/ 09286586.2011.628775

20. Alqudah A, Mansberger SL, Gardiner SK, Demirel S. Vision-related quality of life in glaucoma suspect or early glaucoma patients. $J$ Glaucoma. 2016;25(8):629-633. doi:10.1097/IJG.0000000000000445

21. Welp A, Woodbury RB, McCoy MA, et al., editors. National Academies of Sciences, Engineering, and Medicine; Health and Medicine Division; Board on Population Health and Public Health Practice; Committee on Public Health Approaches to Reduce Vision Impairment and Promote Eye Health. Washington (DC): National Academies Press (US); 2016.

22. Bramley T, Peeples P, Walt JG, Juhasz M, Hansen JE. Impact of vision loss on costs and outcomes in Medicare beneficiaries with glaucoma. Arch Ophthalmol. 2008;126(6):849-856. doi:10.1001/ archopht.126.6.849
23. Friedman AH. Late traumatic wound rupture following successful partial penetrating keratoplasty. Am J Ophthalmol. 1973;7511775119.

24. Raber IM, Arentsen JJ, Laibson PR. Traumatic wound dehiscence after penetrating keratoplasty. Arch Ophthalmol. 1980;981407981409.

25. Topping TM, Stark WJ, Maumenee E, Kenyon KR. Traumatic wound dehiscence following penetrating keratoplasty. $\mathrm{Br} J$ Ophthalmol. 1982;66174-66178.

26. Farley MK, Pettit TH. Traumatic wound dehiscence after penetrating keratoplasty. Am J Ophthalmol. 1987;10444-10448.

27. Binder PS, Abel R, Polack FM, Kaufman HE. Keratoplasty wound separation. Am J Ophthalmol. 1975;80109-80115.

28. Brown SI, Tragakis MP. Wound dehiscence with keratoplasty: complication of the continuous-suture technique. Am J Ophthalmol. 1971;72115-72116.

29. Rehany U, Rumelt S. Ocular trauma following penetrating keratoplasty: incidence, outcome, and postoperative recommendations. Arch Ophthalmol. 1998;116(10):1282-1286. doi:10.1001/archopht. 116.10.1282

30. Nicola M, Alsafi Z, Sohrabi C, et al. The socio-economic implications of the coronavirus pandemic (COVID-19): a review. Int J Surg. 2020;78:185-193. doi:10.1016/j.ijsu.2020.04.018

31. Dubey S, Biswas P, Ghosh R, et al. Psychosocial impact of COVID19 [published online ahead of print, 2020 May 27]. Diabetes Metab Syndr. 2020;14(5):779-788. doi:10.1016/j.dsx.2020.05.035

32. Mehrsafar AH, Gazerani P, Moghadam Zadeh A, Jaenes Sánchez JC. Addressing potential impact of COVID-19 pandemic on physical and mental health of elite athletes. Brain Behav Immun. 2020;87:147148. doi:10.1016/j.bbi.2020.05.011

33. Kretchy IA, Asiedu-Danso M, Kretchy JP. Medication management and adherence during the COVID-19 pandemic: perspectives and experiences from low-and middle-income countries. Res Social Adm Pharm. 2020;S1551-7411(20):30332-30336. doi:10.1016/j.sapharm. 2020.04.007

34. Ghosal S, Sinha B, Majumder M, Misra A. Estimation of effects of nationwide lockdown for containing coronavirus infection on worsening of glycosylated haemoglobin and increase in diabetes-related complications: a simulation model using multivariate regression analysis. Diabetes Metab Syndr. 2020;14(4):319-323. doi:10.1016/j. dsx.2020.03.014
International Medical Case Reports Journal

\section{Publish your work in this journal}

The International Medical Case Reports Journal is an international, peer-reviewed open-access journal publishing original case reports from all medical specialties. Previously unpublished medical posters are also accepted relating to any area of clinical or preclinical science. Submissions should not normally exceed 2,000 words or 4
Dovepress

published pages including figures, diagrams and references. The manuscript management system is completely online and includes a very quick and fair peer-review system, which is all easy to use. Visit http://www.dovepress.com/testimonials.php to read real quotes from published authors. 